\title{
Effects of Sustained Impromptu Speaking and Goal Setting on Public Speaking Competency Development: A Case Study of EFL College Students in Morocco
}

\author{
Latifa El Mortaji ${ }^{1}$ \\ ${ }^{1}$ School of Humanities and Social Sciences, Al Akhawayn University in Ifrane, Ifrane, 53000, Morocco \\ Correspondence: Latifa ElMortaji, School of Humanities and Social Sciences, Al Akhawayn University in Ifrane, \\ Ifrane, 53000, Morocco. Tel: 212-535-862-024. E-mail: 1.elmortaji@aui.ma
}

Received: October 19, 2017 Accepted: January 10, 2018 Online Published: January 15, 2018

doi: $10.5539 /$ elt.v11n2p 82

URL: http://doi.org/10.5539/elt.v11n2p82

\begin{abstract}
Research on impact of sustained impromptu speaking on public speaking competency development is scarce and lacking. The researcher investigated Moroccan college students' public speaking competency development through extemporaneous (i.e. carefully prepared and rehearsed) speech performance, after implementation of a teaching strategy involving treatment through weekly impromptu (i.e., involving little or no preparation) speaking sessions combined with individual goal-setting strategy (teacher feedback). For this purpose, the researcher assessed 64 extemporaneous speeches delivered over the course of a semester using the public speaking competence rubric (PSCR), and observed the students' public speaking progress through 90 impromptu speaking activities using a weekly goal-setting strategy. Results revealed that a combination of sustained impromptu speaking and goal-setting contributed significantly and effectively to public speaking skills development over the course of the semester. They also clearly showed that the teacher's weekly goal-setting strategy played a major role in building speakers' confidence and overall improvement. Considering the linguistic and cultural background of the students involved, together with the speech genres and the instructor's task requirements, new public speaking competency dimensions and sub-dimensions have been identified.
\end{abstract}

Keywords: competency, public speaking, skill development, sustained impromptu speaking, rubric

\section{Introduction}

Public speaking competence is of paramount importance and vital to students' success. Learning effective public speaking skills enables college students to succeed across the disciplines. Research indicates that acquiring good communication skills in the public speaking course enabled students to get good grades in other courses (Dwyer, Carlson, \& Kahre, 2002), and had a positive impact on the way students perceived their 'behavioral competence', 'self-esteem', and their 'willingness to communicate' (Morreale, Hackman, \& Neer, 1995, 1998). In fact, good communication skills are crucial to all students' personal, academic, and professional success (Morreale \& Pearson, 2008).

For the longest time public speaking courses have been used as part of student general education at the sophomore level, as a means to improve their public speaking skills in an academic context; therein, the focus is typically on initiating public speaking skills such as body language, eye contact, vocal variety, conversational style, clear articulation, idea development, organization, confidence, interaction with audience, and meeting allotted time. These skills would be further reinforced through various activities in other classes, such as presentations, competitions (Gui, 2012) and debates.

Considering the fundamental role that the public speaking course plays, it has been deeply investigated by communication scholars, with a view to developing pedagogical techniques and recommendations to be implemented by instructors in the classroom. Two of such aspects that have been widely studied and covered in the literature are (i) public speaking anxiety (PSA) (Metcalfe, 2010; F. Verderber, Sellnow, \& K. Verderber, 2012), and (ii) the use of impromptu speaking as a tool to reduce PSA (Peterson, 2007; El Mortaji, 2017). In this work, the researcher will investigate the use of impromptu speaking as a tool to promote public speaking competency. Specifically, the researcher will use qualitative and quantitative methods to study the effect of applying a classroom strategy that consists in sustained weekly impromptu speeches coupled with instructor 
feedback on public speaking skills development throughout the semester.

\section{Literature Review}

According to the literature, the impromptu speech is a valuable assignment (Hendrix, 1968; Rumbough, 1999) and "if handled properly by the instructor, [it] can be an enormously valuable confidence builder (Lucas, 1998, $\mathrm{p}$. 242). $85 \%$ of instructors assign impromptu speech exercises in their public speaking course, and many require students to deliver a series of impromptu speeches during the semester (Endres, 1992 as cited in Rumbough, 1999, p. 206). The importance of incorporating impromptu speaking activities in Public Speaking and basic communication courses in general has been noted in some research and in textbooks as a means to improving student Public Speaking performance. However, the bulk of research on the use of impromptu speaking concerns PSA reduction (Rumbough, 1999). Such studies focused mainly on the physiological aspects of students while delivering an impromptu speech, like "heart rate and heart rate arousal pattern" among male and female speakers, and sweating (Baldwin \& Clevenger, 1980; Beidel, Turner, \& Dancu, 1985; Booth-Butterfield, 1987; Beidel, Turner, Jacob, \& Cooley, 1989; Puigcerver, Martinez-Selva, Garcia-Sanchez, \& Gomez-Amor, 1989). Other studies specifically described the actual impromptu speaking activities and exercises used (Clark, 1968; Hampton, 1967; Hendrix, 1968; Paul, 1965; Walser, 1959) and how to implement them over the course of the semester (Peterson, 2007), while others examined forensic-focused impromptu research (Reynolds \& Fay, 1987; Sellnow, 1989; Heinz, 2013).

Very few studies focused on the effect of using impromptu speeches on public speaking skill/competency development. Sun Yu-Chih (2008) reports on the integration of the internationally known 'Toastmaster approach' in her EFL public speaking class whereby 18 Taiwanese Students role-played 15 activities, including delivering both extemporaneous and impromptu speeches. Impromptu speaking was used in two ways: (i) spontaneous presentation of the event/competition through 'The role of Master of Table Topics', which enabled the student presenter to freely select topics and choose speakers for each one-minute impromptu speech, and (ii) spontaneous speech delivery of students selected by the Master of Table. Each student role-played at least once a week to ensure they get enough opportunity to practice. At the end of the semester the author gathered students' perceptions of the effectiveness of the toastmaster speech approach through a survey. It revealed students' improvement in their public speaking skills, namely "body language, vocal variety, developing confidence, expression and idea development, and organization", in addition to 'affective and social competence' (p. 126). The Toastmasters approach helped them acquire skills needed for public speaking, including "overcoming stage fright, speech preparation, impromptu speech delivery, understanding the importance of body language, speaking naturally, audience interaction, and presentation style" (p. 125). However, the author Sun Yu-Chih did not illustrate these improvements through examples, and did not report types and subtypes of the listed skills together with related, specific occurrences. In addition, results were based on students' perceptions only, and therefore, there is no indication if all problematic issues were tackled on a weekly basis, or there was some kind of goal-strategy addressing specific and particular skills to improve progressively as the students moved from one speech to another.

In a more recent study, David Girardelli (2017) designed an impromptu speech activity in his/her public speaking course for Chinese ESL learners, using the format of international famous shows like 'American Idol'. The activity was based on storytelling and was inspired by the rules of 'gamification' (i.e. "application of game elements" (p. 157) (Kapp, 2012, as cited in Girradelli). In six groups of four participants, the students played "artificial" fictional roles in a competition like context, with a host and judges. The teams were provided with "story slides" representing different parts of the story, each with a specific organizational pattern (e.g. topical order, cause/effect order, chorological). While the speakers (presenters) enjoyed the freedom of either coming up with their own introduction based on the prompt or reading an already written introduction, they were required to proceed and deliver a creative two-minute impromptu speech and conclusion, following the organizational pattern displayed on the 'story slides'. The impromptu speeches were evaluated in terms of content (based on story slide shown on the screen), structure, body language, eye contact, and paralanguage.

The same activity was evaluated with 81 EFL Chinese Sophomore who delivered this time two impromptu speaking activities 'Dented Helmet vs. Spambot' and the martial arts inspired 'Black Belt Jones'. The students reported in a post impromptu activity survey that "the activity contributed in increasing their confidence in giving a short speech in English without much preparation, helping them to gain a better understanding of how to organize their speeches [chronological order; topical order; spatial; problem /solution order], and increasing their awareness of the importance of nonverbal communication" (p. 158). Thus, the impromptu speech activity proved to meet the intended objectives and learning outcome as set by the researcher (p. 159). However, although the author reported on the students' public speaking skills development, he/she did not demonstrate the nature and 
amount of these skills. In addition, there is no indication if and how the improvements occurred as the students moved from one round (impromptu speech delivery) to another. Finally, like in the previous study, the author's conclusions are mainly based on students' perceptions.

This research comes to bridge the gap in qualitative and quantitative evidence of the effect of using sustained weekly impromptu speeches coupled with instructor feedback on competency development during the course of a 15 weeks semester. It also aims at reporting on skill development after each extemporaneous speech, with detailed accounts on the gained skills.

\section{Methodology}

\subsection{Research Question}

The research question we shall be concerned with in this study is as follows:

RQ 1: Is there a significant difference between students' achievement of public speaking competencies (dependent variable) before and after attending sustained impromptu speaking activities with a goal setting/teacher feedback strategy (independent variables)?

It is worth mentioning that the gained competencies throughout the semester constitute a holistic set of dependent variables that the researcher is trying to measure after weekly treatment through combined impromptus and goal setting strategy (independent variables).

\subsection{Participants}

Public Speaking (COM1301) is one of the basic communication courses offered at Al Akhawayn University in Ifrane (AUI), Morocco, as a common core that all AUI freshmen students are required to take, regardless of their schools/departments and major. To enroll in this course the students are not required to take any speaking proficiency test; however, they should have already taken English Composition I which is the prerequisite of COM1301. One section of Public Speaking course was randomly selected for the study. Therefore, sixteen Moroccan students $(\mathrm{N}=16)$ aged 18 to 20 participated in the study. Like all AUI freshmen students from all majors, the participants were required to take the course in their second or third regular semester at the University with a view to acquiring effective public speaking skills and, therefore, develop effective communication skills, deemed necessary to succeed in other courses and foster their academic career development. Therefore, this sample is homogeneous in the sense that the students were exposed to formal instruction through English language medium for two semesters, and they had no prior experience in public speaking.

\subsection{Procedure}

The participants signed a consent form at the beginning of the spring semester to be involved in the current study. The researcher, also instructor of COM1301, met with the students three times a week for a-fifty-minute class period. As clearly stated in the syllabus, the students were required to produce four extemporaneous speeches and at least six impromptu speeches and activities throughout the semester. While the extemporaneous speeches were carefully prepared then delivered in class once a month, the impromptus were scheduled on a weekly basis. More information about the types of speeches used and the instructor's requirements are presented in the next section.

\subsection{Data Collection}

The researcher collected qualitative and quantitative data through (i) annotation and evaluation of videotaped extemporaneous speeches using the public speaking competence rubric (PSCR) to highlight exact gained skills and achieved competencies for each extemporaneous speech performance, (ii) grades earned for each extemporaneous speech, and (iii) individual goals assigned for each speaker after each extemporaneous speech.

\subsubsection{Extemporaneous Speeches}

After introducing in class textbook chapters pertaining to different types of speeches, students were instructed to start preparing their extemporaneous speech outside the classroom, and were asked to practice at least ten times before coming to class. The 'self-introduction speech using an object' was the first and the easiest of the four extemporaneous speeches, which served as an ice breaker, and was delivered in week 2 . The same process was followed in subsequent speeches, the 'informative', the 'persuasive', and the 'special occasion' speech, except that (i) the allotted time changed from 3 to 5 and 6 minutes, respectively, (ii) the students were required to research their topic and compile a bibliography, and (iii) they were instructed to produce an outline. These last three speeches were, therefore, more demanding, and the students needed to spend more time preparing them. Overall, the four extemporaneous speeches were delivered in weeks 2, 6, 10 and 14, respectively. As for speech 
assessment, the PSCR (see 3.4.1) was used, and the assigned grades counted 5\%, 10\%, 15\%, and 15\%, respectively, towards the final course grade. So, the first main source of data collection in this study is the four extemporaneous speeches that the researcher videotaped, together with the scored PSCR sheets for each speech.

\subsubsection{Impromptu Speeches}

Starting week 3 through week 15, the instructor scheduled impromptu speeches and oral activities almost every Friday; therefore, ten impromptu sessions were offered during the semester. In total, the 16 students delivered 90 impromptu speeches, including group/collaborative and individual impromptu speeches. The purpose of these impromptu sessions was to practice delivering speeches to an audience on a weekly basis so as to strengthen public speaking skills and develop confidence. Given that the participants had no past experience speaking in front of an audience, the impromptu speeches were preceded by warm-up activities like breathing exercises and fun group activities, such as storytelling, for relaxation and classroom connectedness, in order to build trust and confidence within themselves and between each other, and alleviate stress and anxiety feeling. Regarding topic selection, the students were called on just a few minutes before delivering a complete and structured impromptu speech to an audience. The list of topics changed every week. This way, the students had to think on their feet for they had no prior knowledge of the topics. Unlike extemporaneous speeches, the impromptu speeches were not individually graded, but $10 \%$ of the overall course grade was assigned to impromptus. This way, the main focus of the students was on implementing their teacher's feedback and achieving their goals, without being stressed or anxious about failing their speech. Thus, the weekly impromptu speeches were used for practice purposes as treatment of areas that needed improvement and weaknesses pre-identified in each extemporaneous speech. An overall schedule of these impromptu sessions and the graded extemporaneous speeches is presented in Table1.

Table 1. Schedule of treatment sessions and extemporaneous speech delivery

\begin{tabular}{llll}
\hline Weeks & $\begin{array}{l}\text { Impromptu Speaking Sessions \& Weekly Goal-Setting } \\
\text { (treatment) }\end{array}$ & $\begin{array}{l}\text { Extemporaneous } \\
\text { (graded and assessed } \\
\text { PSCR) }\end{array}$ \\
\hline Week 1 & - & - \\
Week 2 & - & $\begin{array}{l}\text { Speeches } \\
\text { using }\end{array}$ \\
Week 3 & 1 & - \\
Week 4 & 1 & - \\
Week 5 & 1 & - \\
Week 6 & - & $\begin{array}{l}\text { Informative Speech (after } \\
\text { treatment) }\end{array}$ \\
Week 7 & 1 & - \\
Week 8 & 1 & - \\
Week 9 & 1 & - \\
Week 10 & 1 & - \\
Week 11 & - & $\begin{array}{l}\text { Persuasive Speech with Visuals } \\
\text { (after treatment) }\end{array}$ \\
Week 12 & 1 & - \\
Week 13 & 1 & - \\
Week 14 & 1 & - \\
Week 15 & - & Special Occasion Speech (after \\
Total & 10 Impromptu Speaking Sessions & treatment) \\
\hline
\end{tabular}

\subsubsection{Goal Setting Strategy}

The participants received teacher feedback for each performance. Using the instructor's goal-setting strategy, 
each speaker had her/ his own goals to focus on every week, and practiced different aspects of their speech in order to, eventually, improve them by the next graded extemporaneous speech. In other words, and as clearly stated in the course syllabus, the students' success or failure in the course depended on how well they did in the extemporaneous speeches. As for the impromptu speaking sessions, they were used by the professor as a teaching tool to help the students practice on a weekly basis and set specific goals for improvement. The continuous feedback the instructor provided was based on the weaknesses highlighted in each extemporaneous speech, and the instructor taught the students to set different goals for each impromptu speaking session in order to tackle all their individual problematic issues progressively, and make the required improvements by the time the next extemporaneous speech was due.

\subsection{Materials}

The researcher used the Public Speaking Competence Rubric (PSCR) starting week 6, after three treatment sessions were implemented, to assess the students' extemporaneous speeches and measure their achieved competencies.

\subsubsection{The Public Speaking Competence Rubric (PSCR)}

The researcher chose to use the Public Speaking Competence Rubric (Schreiber et al., 2012) to assess the students' extemporaneous speeches, which is quite compatible with the course textbook the Art of Public Speaking (Lucas, 2011), and close to the list of competencies and requirements studied in class. At the end of each speech delivery, the students were provided with a copy of their speech assessment (i.e. scored PSCR), and an overall holistic grade to give them a clear and accurate idea about their strengths and the areas they needed to improve. This feedback was emphasized in the weekly impromptu speaking sessions where the students were required to focus on the dimensions they needed to improve, one at a time, in order to improve their public speaking skills progressively.

The PSCR (see appendix) consists of 11 competencies or dimensions, namely 1. topic selection, 2. introduction, 3. organization, 4. supporting material, 5. conclusion, 6. word choice, 7. vocal expression, 8. nonverbal behavior, 9. audience adaptation, 10. visual aids, and 11. persuasiveness, on a five-step competence scale, 4 being advanced, 3 proficient, 2 basic, 1 minimal, and 0 deficient.

As for the validity of the PSCR, Schreiber et.al conducted two sets of studies and analyzed 95 informative and persuasive speeches, 45 and 50 respectively, that were coded by experts and non-experts "to check the [inter-rater] reliability, factor structure, and validity of the PSCR" (p. 216). The results showed that the PSCR "was an effective tool at assessing students' public speaking competence", and "appears to be a robust instrument for use in the classroom and as an assessment tool" (p. 225). The researchers also compared the grades the participants had received in the informative and persuasive speeches to the PSCR scores and found that the comparison "supported the measure's predictive validity". Overall, the researchers confirmed the PSCR "to be a consistent and accurate measure of public speaking ability" (p. 205).

It is worth mentioning here that; (a) some of these 11 competencies were not used when assessing the informative speech and special occasion speech, such as dimensions 10,11, and 10, respectively, and (b) new dimensions and sub-dimensions emerged in the study, reflecting first the linguistic and cultural background of the EFL students, second the type of assigned speeches, such as the special occasion speech, and third, the instructor's specific task requirements, such as the use of an outline. Therefore, the emergence of these new dimensions/sub-dimensions that were identified across the four extemporaneous speeches necessitated for the purpose of this study a slight adaptation to the original Public Speaking Competence Rubric.

\section{Data Analysis and Results}

As stated earlier, in order to investigate the impact of weekly impromptu speaking and goal setting strategy on students' public speaking competency development in four extemporaneous speeches delivered in the course of a semester, the researcher used as measure a public speaking competence rubric (PSCR) that she slightly adapted based on the nature of the speeches used, specific task requirements, and the background of the participants involved. The combination of this rubric (i.e., each student received one scored rubric for each of the four extemporaneous speeches) and the teacher's weekly observation and goal-setting strategy implemented in impromptu speaking (i.e., treatment) were used with the purpose of getting reliable, accurate data, and a clear understanding of the topic under investigation. Data were analyzed both qualitatively and quantitatively. The results are presented hereafter.

\subsection{Qualitative Data Analysis}

The students were assigned four extemporaneous speeches: Self-introduction, informative, persuasive with 
visuals, and special occasion (i.e. commemorative; acceptance; introduction; graduation). Based on the speech genre, the instructor made specific requirements about the purpose of the speech, audience analysis, supporting material, organization, outline, language, and allotted time. The researcher evaluated the performance of the students in terms of the 11 dimensions of the PSCR (see 3.4.1), in addition to new, emerging dimensions and sub-dimensions (see Tables 3, 4, 5, 6), and assigned an overall grade that clearly showed to what extent the specified competencies (i.e. dimensions) were achieved in every speech. The instructor scored 64 extemporaneous speeches ( 4 speeches per student), and the overall grades are presented in Table 2.

4.1.1 Assigning a Holistic Score

Table 2. Students' grades (\%) in the four extemporaneous speeches

\begin{tabular}{lllll}
\hline Students & $\begin{array}{l}\text { Speech 1 } \\
\text { Self-introduction } \\
* * \text { (before treatment) }\end{array}$ & $\begin{array}{l}\text { Speech 2 } \\
\text { Informative } \\
* * \text { (after treatment) }\end{array}$ & $\begin{array}{l}\text { Speech 3 } \\
\text { Persuasive } \\
* * \text { (after treatment) }\end{array}$ & $\begin{array}{l}\text { Speech 4 } \\
\text { Special } \\
\text { Occasion } \\
* * \text { (after } \\
\text { treatment) }\end{array}$ \\
\hline 1 & & & & 91 \\
2 & 89 & 97 & $90^{*}$ & 93 \\
3 & 88 & 96 & $89^{*}$ & 97 \\
4 & 90 & 89 & 93 & 90 \\
5 & 75 & 82 & 86 & 93 \\
6 & 84 & 95 & $90^{*}$ & 97 \\
7 & 75 & 83 & 91 & 90 \\
8 & 75 & 83 & 89 & 89 \\
9 & 81 & 83 & 86 & 93 \\
10 & 84 & 90 & 92 & 93 \\
11 & 85 & 93 & $89 *$ & 93 \\
12 & 72 & 89 & 91 & 90 \\
13 & 80 & 84 & 89 & 90 \\
14 & 73 & 80 & 85 & 93 \\
15 & 83 & 88 & 92 & 91 \\
16 & 88 & 90 & 90 & 89 \\
\hline
\end{tabular}

Note. ${ }^{*}$ Low scores in the persuasive speech. $* *$ The treatment is impromptu + goal-setting.

As observed in Table 2, all sixteen students received higher grades as they moved from speech 1 to speech 4 . On the other hand, 4 out of 16 students received grades in speech 3 slightly lower $(89 \% ; 90 \%)$ than in speech 2 (93\%; 95\%; 97\%).

In addition to the assigned grades, a detailed analysis of the achieved and non-achieved public speaking competencies across the four extemporaneous speeches is presented in the next sections, using the PSCR, to shed more light on the students' public speaking competence development over the course of the semester.

\subsubsection{Speech 1: Self-Introduction Speech}

The self-introduction speech is intended to evaluate the public speaking skills of each participant before impromptu and goal-setting sessions. 
Table 3. Students' public speaking competence in the self introduction speech

\begin{tabular}{lll}
\hline Speech & Students' Non Achieved Public Speaking Competencies & $\begin{array}{l}\text { Students' } \\
\text { Public } \\
\text { Competencies }\end{array}$ \\
\hline
\end{tabular}

Speech\#1 16/-non-verbal behaviors: 10 nervous gestures (hands shaking; voice trembling; sudden stops, inability to continue the speech; confusion; loss of words; tongue clicks; sighs; unexpected / too serious facial expressions; biting lips ); 6 posture (moving back and forth; playing with one foot; leg crossing; bouncing; hands in pocket; crossing arms in front ; crossing arms behind back; holding one arm; leaning on one leg; leaning on desk); 9 -Eye contact: (looking up at ceiling; looking down; avoiding looking at faces of audience members; fixing the wall; maintaining eye contact with instructor only; turning back to one side of class 'audience')

7-Mannerism: (touching hair; touching beard; repeatedly adjusting 5/-Introduction: good attention grabber; preview of the main points; clear central idea;

\section{1/-Supporting}

materials: examples; good idea development;

6/-Conclusion: going back to central idea; using a quote; scarf; scratching face /nose; waving hands; pointing; playing with necklace/bracelet; pulling shirt / dress down; looking through window; chewing gum)

14/-topic selection: 4 -inappropriate topic (failure to relate object to self; did not use an object as required; missed the purpose); 10 allotted time (beyond or below allotted time)

12/-vocal expression: 8 voice (filled pauses; low voice; monotonous tone); 4 speaking rate (too fast due to reciting; out of breath; too excited; too slow); 6 foreign accent (word stress; clear influence of Arabic or French accent); 4 foreign intonation (influence of Moroccan Arabic intonation); speaking inaudibly (swallowing word ending);

6 /-word choice: language (limited vocabulary; repetition of word/word groups; inappropriate word choice; informal language; sexist terms); grammar errors; mispronounced words (due to $2^{\text {nd }}$ language influence);

Note. ${ }^{*}$ Underlined new/emerging sub-dimensions reflect linguistic and cultural background of EFL students.

As shown in Table 3, EFL students' achieved public speaking competencies in speech 1 were mainly found at three levels; the body of the speech, i.e. using supporting material like idea development and examples (11 students), followed by the conclusion, i.e. going back to the central idea and ending beautifully with a quote (6 students), and the introduction, i.e. using an attention grabber and previewing the main points (5 students). On the other hand, the non-achieved competencies exceeded the achieved competencies by far. In total, the following cases were noted: all (16) students had nonverbal behaviors issues, i.e. 32 behavior instances were observed, including 10 nervous gestures, 6 posture cases, 9 eye contact, and 7 cases of mannerism. In addition to non-verbal behaviors, there were problems with topic selection, including choosing inappropriate topics, missing the purpose of the topic, and not respecting allotted time (14 students), followed by vocal expression, where new dimensions and sub-dimensions emerged like word stress, foreign accent, and foreign intonation due to influence of L1 (Arabic) and L2 (French) (12 students), and finally word choice, such as using informal or inappropriate language, using a few sexist terms, wrong word choice, word and group of words repetition due to limited vocabulary, a few grammatical mistakes, and mispronounced words (6 students). The underlined dimensions and sub-dimensions in Table 2 indicate that these emerging behaviors reflect the linguistic and cultural background of EFL speakers.

During the first speech delivery, it was quite obvious that many students had memorized their complete speech before coming to class, which explains their low eye contact with the audience since they were gazing somewhere else to remember their speech and recite it, using fast speech rate, and when they forgot one word they were lost, stuck, and struggled to find a substitute, and often failed to move on or finish their speech. All these behaviors explain the low grades the students received in the first speech (see Table 2). The students' low 
performance was expected in the first speech because the weekly impromptu sessions (used for practice) were scheduled for week 3, while the self-introduction speech was delivered in week 2.

\subsubsection{Speech 2: Informative Speech}

Table 4. Students' public speaking competence in the informative speech

\begin{tabular}{ll}
\hline Speech & $\begin{array}{l}\text { Students' Non Achieved Public } \\
\text { Competencies }\end{array}$ \\
\hline Speech\#2 & 6/topic selection: 6 allotted time (going over or under); \\
& $\begin{array}{l}\text { 3/supporting materials: } 3 \text { Body (using two main } \\
\text { points instead of three as required; no source citations); }\end{array}$ \\
& $\mathbf{5} /$ non-verbal behaviors: 5 eye-contact (occasionally \\
& looking at ceiling or ground; facing professor \& giving \\
& back to part of the class); 5 relying on notes (reading \\
& occasionally; ineffective note cards: A4; full text on \\
& note cards);
\end{tabular}

2/outline 1. Length (produced a brief topic outline instead of a sentence one as required); 1 . Structure (did not use .... to clearly identify main points, from sub-points and sub-subs)

1/organizational pattern: 1. Mixed topical \& chronological (confusing structure; no transitions);

\section{Students' Achieved Public Speaking} Competencies

14/organizational pattern: good flow of ideas; clear division /organization of main parts; a well written and clearly structured outline; clear \& consistent organizational pattern;

13/word choice: clear language; appropriate word choice;

14/non-verbal behaviors: 10 Posture (good posture; relaxed; walking on stage); 11 eye-contact (maintaining good eye contact with all audience members); Note Cards but no reading (appropriate size / discreet; brief notes: key words; used to keep hands busy OR as a back- up in case they get confused)

14/adapting speech to audience: showing importance of information (relating topic to audience); slight interaction with audience (funny; pleasant reaction to audience comments; direct communication with audience using WH questions);

11/vocal expression: speaking naturally; adopting a conversational style;

10/topic selection: using original \& interesting topics; respecting allotted time;

Note. *Underlined new/emerging dimension and sub-dimensions relate to culture, the type of speech used \& teacher's requirement.

As shown in Table 4, in speech 2 the students made big improvements at all levels. This clearly illustrates the high impact of impromptu speaking practice on the students' skills development in terms of speech preparation, speech delivery, and confidence. Indeed, all 16 participants had delivered 3 individual impromptus and 2 group impromptu activities before delivering speech 2. As shown in Table 3,89\% of students met the informative speech requirements in terms of content, structure and organization of the speech, language use, word choice, audience adaptation, non-verbal behaviors, confidence, topic selection, and even delivered their speech within allotted time. The weekly impromptu speaking practice helped the speakers become comfortable and more at ease delivering a speech in English as a foreign language, since they showed their ability in interacting with the audience, telling jokes, speaking spontaneously, and responding spontaneously in English to some of the audience members' reactions. Most speakers refrained from writing a whole speech in English and memorizing it. It was quite obvious during their speech presentation that their delivery was extemporaneous; most of them adopted a conversational style and started speaking naturally. In addition, they had no problem finding another word as a substitute to express an idea or a thought, they showed much less struggle finding the right word choice and expression, and they even used better note cards with less text compared to speech one. 


\subsubsection{Speech 3: Persuasive Speech with Visuals}

Table 5. Students' public speaking competence in the persuasive speech with visuals

\begin{tabular}{ll}
\hline Speech & $\begin{array}{l}\text { Students' Non Achieved Public } \\
\text { Speaking Competencies }\end{array}$ \\
\hline Speech\#3 & 4/visual aids: speaker did not practice \\
& with visual aids; \\
& 3/organization: 1 structure (no clear \\
& organizational pattern); 1. Wrong \\
& organizational pattern for type of \\
& topic (speaker not sure if addressing \\
& question of Value or Policy; \\
& Problem-solution order or Monroe's \\
& motivated sequence); 1 audience \\
analysis (no reference to the audience \\
analysis questionnaire as required).
\end{tabular}

16/content: all requirements met at the levels of introduction (attention getter; establishing credibility; specific purpose and central idea; audience analysis questionnaire; visual aids), body (main points well organized; supporting materials; citing sources; sound reasoning; transitions; visual aids), and conclusion (signpost; summary; clincher; call to action); outline (detailed, well written, well structured)

16/eye contact: fully maintained with all audience members;

16/posture: professional; many enjoyed walking; using appropriate gestures;

15/language: clear, vivid language; grammar (accurate, fluent, correct English); word choice (appropriate; selective)

15/timing: presenting within allotted time;

15/confidence: absence of nervous gestures \& mannerism; poise

15/vocal variation: adjusting voice and tone to setting and speech occasion; adopting conversational style;

14/audience adaptation: very well considered through speech preparation and delivery; effective connection and interaction with audience; stressing the You; humor;

14/effective persuasion: clearly stating the problem \& solution; supporting claims with credible evidence

13/effective organizational pattern: clear main points, effective transitions and signposts;

12/visual aids: selective; high quality; well presented;

Note. *Underlined new/emerging sub-dimensions relates to the type of speech used \& instructor's requirement.

In speech 3 it was quite striking to see how all 16 students had a full understanding of the content and structure of their speech assignment. As illustrated in Table 5, 16 students succeeded in giving all the essential elements in the introduction, namely the attention getter, establishing credibility by referring to their sources, stating the specific purpose and central idea, then using good transitions to move from one part to another. Most students (14) stated the results of their audience analysis questionnaire and used a clear organizational pattern. Also, they submitted detailed and well-structured outlines. As for the non-verbal behaviors, 15 students maintained good eye contact with the audience and managed to adjust and control their voice and tone. They were quite confident standing in front of an audience; in fact, many of them who maintained a straight standing posture in speech one started walking confidently in the classroom, using appropriate gestures, and took their time to breathe naturally, using a conversational style. In addition, 14 out of 16 students adapted their speech to the audience throughout the process of topic selection, speech preparation and delivery, and learned how to create a bond with the audience members and have a pleasant and enjoyable interaction with them using different techniques, like stressing the 'you', asking questions, and using humor. As for visual aids, 12 students were selective in choosing appropriate visuals to help them support their thesis and claim, while 4 students did not take this task seriously 
and did not even bother to practice using their visuals while rehearsing (practicing) their extemporaneous persuasive speech before coming to class. This explains the reason these speakers in particular received low scores in the persuasive speech compared to other three speeches, as clearly illustrated in Table 1.

\subsubsection{Speech 4: Special Occasion Speech}

Table 6. Students' public speaking competence in the special occasion speech

\begin{tabular}{|c|c|c|}
\hline Speech & $\begin{array}{l}\text { Students' Non Achieved Public Speaking } \\
\text { Competencies }\end{array}$ & $\begin{array}{llll}\begin{array}{l}\text { Students' Achieved } \\
\text { Competencies }\end{array} & \text { Public } & \text { Speaking }\end{array}$ \\
\hline \multirow[t]{6}{*}{ Speech\#4 } & $\begin{array}{l}\text { 2/Persuasion: } \text { not convincing of the role } \\
\text { played and the special occasion; }\end{array}$ & $\begin{array}{l}\text {-The PSCR: } 10 \text { out of } 11 \text { dimensions were fully } \\
\text { acquired; }\end{array}$ \\
\hline & $\begin{array}{l}\text { 2/Physical appearance: not appropriately } \\
\text { dressed up for the occasion; }\end{array}$ & $\begin{array}{l}\text { 16/Overall delivery: strikingly effective and } \\
\text { professional; }\end{array}$ \\
\hline & & $\begin{array}{l}\text { 16/Audience: highly engaging; pleasant } \\
\text { interaction with the audience; }\end{array}$ \\
\hline & & $\begin{array}{l}\text { 16/Stage performance: strong presence on stage } \\
\text { of auditorium }\end{array}$ \\
\hline & & $\begin{array}{l}\text { 16/Confidence: completely relaxed, no signs of } \\
\text { anxiety observed }\end{array}$ \\
\hline & & $\begin{array}{l}\text { 14/Physical appearance: appropriately dressed } \\
\text { up for the occasion }\end{array}$ \\
\hline
\end{tabular}

Note. *Underlined new/emerging dimension and sub-dimension relate to the type of speech used.

As shown in Table 6, all 16 students demonstrated striking improvement and effective public speaking skills at all levels in speech 4. At this stage, each speaker had delivered between 6 and 9 impromptu speeches and activities. The students had received intensive practice through sustained impromptu speaking whereby they benefited from the instructor's feedback and adapted a weekly goal-setting strategy to tackle different problematic issues pertaining to their speech preparation, speech delivery, and confidence, which contributed largely and effectively to the spectacular results achieved in their public speaking competence and performance confidence as clearly illustrated in Table 5. All students demonstrated effective behaviors in terms of the PSCR dimensions. Given the nature of the speech, i.e. special occasion, new dimensions emerged here like convincing the audience of 'the role' the speakers played while delivering an acceptance speech or a graduation speech. This dimension did not apply in the case when some students delivered a commemorative speech. Another dimension is the physical appearance that the students were informed of beforehand, but some students did not respect this requirement, which did have an impact on them not convincing the audience of who they were supposed to be and the special occasion of their speech. Finally, considering the nature of this last speech, the instructor chose the university 'auditorium' as the venue for the students' speech presentation, which was quite a challenge to them, and the students succeeded in perfectly adjusting their eye contact, posture, and voice to the new venue and delivering an effective and professional stage performance.

\subsection{Quantitative Data Analysis}

\subsubsection{Data Preparation}

To proceed with the quantitative data analysis and hypothesis (RQ1) verification, the grades for the first (before treatment) and last (after treatment) extemporaneous speeches were compiled by student ID, and tabulated into a Microsoft Excel sheet.

In order to analyze the results and to answer the research question i.e., determine the effect of impromptu speeches and teacher feedback on competency development over the course of a semester, means and standard deviations were computed for the tabulated grades (see Table 7). 
Table 7. Grades for pre and post treatment

\begin{tabular}{lllllllllllllllllll}
\hline Students & & & & & & & & & & & & & & & & & \\
& $S 1$ & $S 2$ & $S 3$ & $S 4$ & $S 5$ & $S 6$ & $S 7$ & $S 8$ & $S 9$ & $S 10$ & $S 11$ & $S 12$ & S13 & S14 & S15 & S16 & Mean & St. Dev \\
\hline Speech \#1 & 90 & 88 & 90 & 75 & 84 & 75 & 75 & 81 & 84 & 85 & 72 & 80 & 73 & 83 & 88 & 85 & 81.75 & 5.91 \\
Speech \#4 & 91 & 93 & 97 & 90 & 93 & 97 & 90 & 89 & 93 & 93 & 93 & 90 & 90 & 93 & 91 & 89 & 92.00 & 2.40 \\
Variation & & & & & & & & & & & & & & & & & $-10.25 \%$ & $-13 \%$ \\
\hline
\end{tabular}

Table 8 shows the distribution of competency skills pre and post impromptu. As can be seen therein, the number of students with fair to moderate skills jumped from 12 to 0 , indicating that all students benefited from impromptu and feedback by the end of the semester (speech \#4).

Table 8. Distribution of skill level

\begin{tabular}{lll}
\hline & Before treatment & After treatment \\
\hline Fair Skills $(<75)$ & 2 & 0 \\
Moderate Skills $(75-85)$ & 10 & 0 \\
High Skills $(>85)$ & 4 & 16 \\
\hline
\end{tabular}

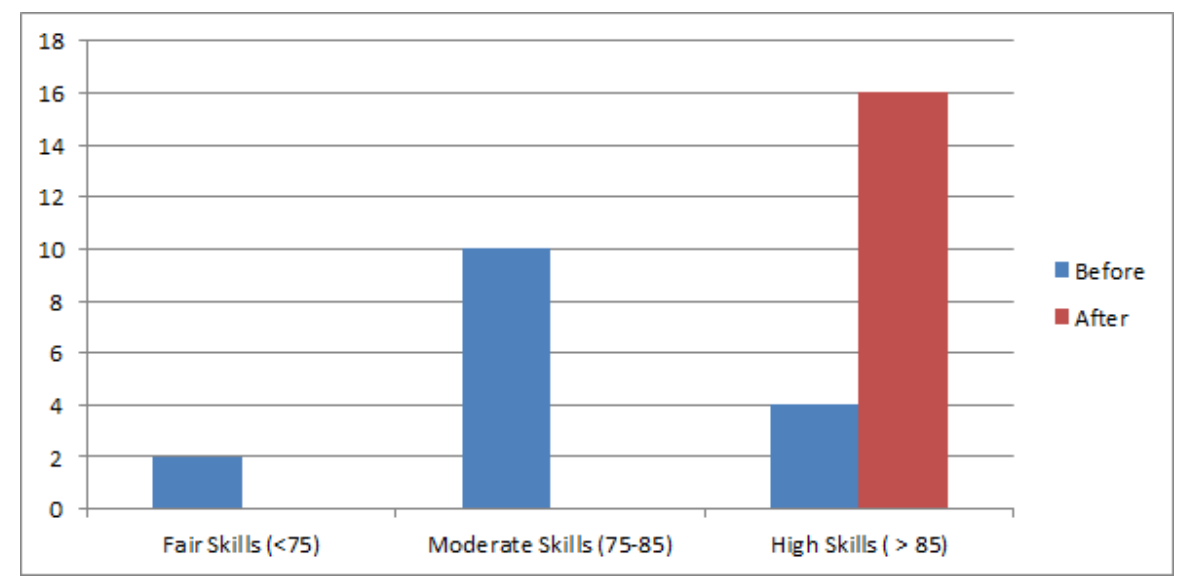

Figure 1. Distribution of skill levels pre and post impromptu

\subsubsection{Hypothesis Testing and Research Question Findings}

The means we found are as follows: pre impromptu 81.75 and post impromptu 92 . The mean difference is 10.25 representing as much as $10 \%$ increase in skills. This supports our hypothesis which is "sustained impromptu speaking with weekly teacher feedback significantly increased public speaking skill level." To eliminate any effects of chance, we further performed a paired t-test, which compares the means of two groups with paired observations (i.e., before and after measurements) by computing the differences in means for individual students. In doing so, Alpha was set to 0.05 , so that we have only a $5 \%$ chance of making a Type I error, which would make the results statistically insignificant. The t-value found using a 1-tailed distribution is $=0,000003981$, which is much less than the 1-tailed p-value for the sample 2,131 , indicating that the $10 \%$ average increase in skill level is not subtitle, and is not the result of chance.

Figure 2 shows the progression of the average grades throughout the semester. As much as $60 \%$ of the overall progress is achieved after the feedback obtained from the initial speech. 


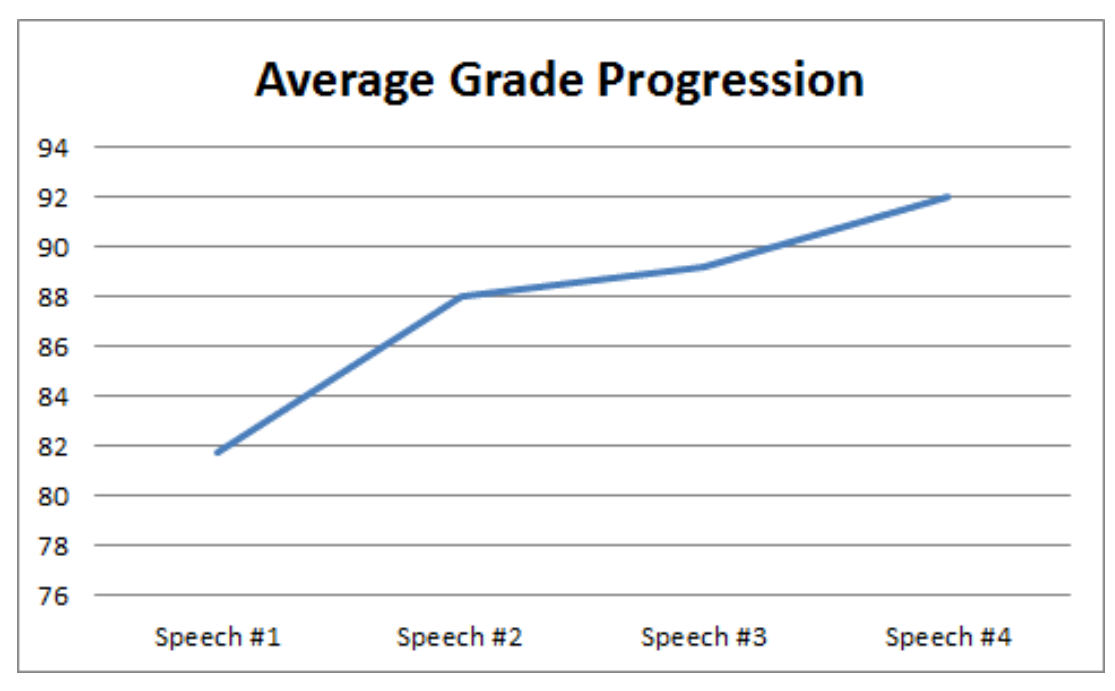

Figure 2. Skill development progress

\section{Discussion}

The purpose of this study was to determine whether sustained impromptu speeches coupled with teacher's feedback improved students' public speaking skills in the course of a semester. The researcher used a public speaking competence rubric (PSCR) as a measure. The students' improvement in speech preparation, speech delivery, and confidence clearly revealed that there is a correlation between public speaking competency development and intensive practice through sustained impromptu speaking.

The PSCR measured the students' competencies in four extemporaneous speeches delivered throughout the semester and demonstrated high improvement in the speakers' performance in terms of many competencies. The dimensions that seemed to be most problematic to the participants in the first speech were 'non-verbal behaviors', followed by 'topic selection', 'vocal expression', 'language', and 'word choice'. After practicing through three impromptu speaking sessions, the students showed major improvement in the second extemporaneous speech at the level of these specific dimensions, in addition to a variety of other competencies pertaining to general 'language use', 'content', 'organization', 'delivery', and 'confidence'. In subsequent extemporaneous speeches, the students made substantial public speaking competence development in all dimensions thanks to sustained impromptu speaking. In addition, new dimensions and sub-dimensions emerged to highlight the nature of new speech genres as well as the linguistic and cultural background of the EFL students. These new emerging dimensions were identified and added to the original PSCR, as clearly illustrated in the analysis part (see Tables $3,4,5,6$ ). Therefore, these new dimensions and sub-dimensions pertain to (i) language use, word choice, intonation, accent, word stress, (ii) nonverbal behaviors, such as posture, mannerism, gestures, eye contact, and (iii) outline, audience analysis questionnaire, physical appearance, speech situation, and, therefore, make a clear and interesting contribution to the 'adapted version' of the PSCR by making it more descriptive and informative than the original one. This calls for a need to conduct similar studies to develop a comprehensive EFL public speaking competence rubric to accommodate public speakers of English as a second or a foreign language in an academic context.

The teacher's constructive feedback using the weekly goal-setting strategy proved to be very effective and rewarding. Indeed, thanks to the weekly provided feedback, each student had his/her own goals to achieve on a weekly basis. Breaking overall goals into sub-goals for each impromptu delivery proved to be an effective and fruitful strategy that contributed tremendously to improving areas of weaknesses in the students' public speaking performance. This confirms results from previous studies about the importance of feedback and goal setting strategy to improve "speaking abilities" (De Grez et al., 2009).

Teacher's observation of the students' weekly impromptu speaking performance revealed that these sessions contributed to classroom connectedness. Indeed, instructor's support, class discussion, and collaborative impromptu activities helped create a warm, supportive learning environment where the student speakers felt secure and at ease with each other, which in turn contributed to building the students' confidence to a large extent. They were not afraid anymore of standing alone in front of an audience and receiving feedback from the 
instructor and their peers. This confirms Weaver and Qi's finding in 2005 that "Peer interactions significantly influence the classroom climate" and "perceptions of the audience and audience feedback play a pivotal role in public speaking anxiety" (McIntyre \& MacDonald, 1998; Sidelinger et al., 2011; Edwards \& Walker, 2007). The fact that the COM1301 class was a small-class size did contribute to individualized attention from instructor and student communication.

\section{Limitation of the Study}

The researcher involved in this research one section of public speaking students only, which represents a small sample size. So future research should consider involving two or more student sections to ensure obtaining a larger sample size.

\section{Conclusion and Recommendations}

The teaching method adopted in this study proved to have significant effects on students' public speaking competence development. Indeed, sustained impromptu speaking practice has been demonstrated to be highly effective in improving public speaking performance and developing confidence in an academic setting. The analysis part clearly demonstrated the quality and frequency of skills' improvement the students made across the four extemporaneous speeches. Major improvement pertained to non-verbal behaviors, followed by content, organization, then language, which in turn had a positive impact on building confidence. However, results revealed some students' unachieved competencies in the persuasive speech, mainly because new dimensions /sub-dimensions were introduced based on the nature of the speech and the instructor's requirements. For example, results revealed that some students had problematic issues with visual aids and organizational patterns, which affected their performance and therefore their grade. Thus, it is recommended to do more impromptus in the persuasive genre, to ensure students get extra training and practice in this speech genre that, as demonstrated, proved to be more complicated and demanding to some students. In addition, the instructor could require visuals for the informative speech as well, in addition to the persuasive, to enable the students to practice more with visuals and gain the required skills.

Also, the teacher's weekly goal-setting strategy enabled the students to see and assess the process of their specific skill development as they moved from one speech to another. Therefore, this teaching method is recommended as an effective strategy and tool to be implemented in the basic public speaking course, to reinforce classroom instruction and meet the learning objectives of the course, i.e. communication skills, deemed necessary to succeed in their academic career.

As for the modified version of the PSCR, new dimensions and sub-dimensions emerged due to the linguistic and cultural background of the EFL participants, as well as the type of speeches used. This calls for a need to develop a more comprehensive ESL/EFL public speaking competence rubric to (i) accommodate public speakers of English as a second or a foreign language in an academic context and (ii) all possible speech genres.

\section{Future Research}

As demonstrated in the literature review, the existing research on the impact of weekly/ sustained impromptu speaking on students' public speaking competency development over the course of a semester is scarce, even lacking. Communication scholars investigated different factors contributing to public speaking skills development, such as anxiety reduction, but the impact of sustained impromptu speaking has been neglected in the literature. Thus, there is a need to explore this area in future research, and why not duplicate the current study. Also, 'venue' (in this study it was 'auditorium') is a new aspect that the researcher did not initially intend to study as a factor impacting students' performance, and that, by chance, was revealed important in the fact that it contributed positively to the students' adjustment in terms of some behaviors, namely voice, eye contact, and even posture, which eventually contributed to an effective and professional performance. In future research, it should be interesting to explore the impact of a large-size space vs. a small-size space on students' public speaking performance. Finally, investigating the correlation of public speaking anxiety, public speaking competency development, and sustained impromptu speaking would be an interesting venue to explore both quantitatively and qualitatively in future research.

\section{References}

Baldwin, S. F., \& Clevenger, T. (1980). Effect of speaker's sex and size of audience on heart-rate changes during $\begin{array}{lllll}\text { short impromptu } & \text { speeches. Psychological Reports, }\end{array}$ https://doi.org/10.2466/pr0.1980.46.1.123

Beidel, D. C., Turner, S. M., \& Dancu, C. V. (1985). Physiological, cognitive and behavioral aspects of social anxiety. Behavior Research and Therapy, 23(2), 109-117. https://doi.org/10.1016/0005-7967(85)90019-1 
Beidel, D. C., Turner, S. M., Jacob, R. G., \& Cooley, M. R. (1989). Assessment of social phobia. Journal of Anxiety Disorders, 3(3), 149-158. https://doi.org/10.1016/0887-6185(89)90009-1

Booth-Butterfield, S. (1987). Action assembly theory and communication apprehension: A Psychophysiological study. Human Communication Research, 386-398. https://doi.org/10.1111/j.1468-2958.1987.tb00111.x

Booth-Butterfield, S. (1988). Instructional interventions for reducing situational anxiety and avoidance. Communication Education, 37, 214-223. https://doi.org/10.1080/03634528809378721

Clark, F. (1968). Let them all speak. Today's Speech, 15(2), 25-26. Cited in Rumbough, T. B. (1999). The effects of impromptu speech exercises on reducing trait and situational communication apprehension. The New Jersey Journal of Communication, 7(2), 206-215. https://doi.org/10.1080/01463376809385478

De Grez, L., Valcke, M., \& Roozen, I. (2009). The impact of an innovative instructional intervention on the acquisition of oral presentation skills in higher education. Computers \& Education, 53(1), 112-120. https://doi.org/10.1016/j.compedu.2009.01.005

Dwyer, K., Carlson, R., \& Kahre, S. (2002). Communication apprehension and basic course success: The lab-supported public speaking course intervention. Basic Communication Course Annual, 16, 87-112.

Edwards, C., \& Walker, S. (2007). Using public speaking learning communities to reduce communication apprehension. Texas Speech Communication Journal, 32, 65-71.

El Mortaji, L. (2017). Effects of Sustained Impromptu Speaking on Public Speaking Anxiety Reduction. Journal of Emerging Trends in Educational Research and Policy Studies (JETERAPS), 8(4), 216-222.

Endres, T. G. (1992). Impromptu speaking: Classroom applications of the forensic model. Paper presented at the Speech Communication Association in Chicago, IL. Cited in Rumbough, T. B. (1999). Cited in Rumbough, T. B. (1999). The effects of impromptu speech exercises on reducing trait and situational communication apprehension. The New Jersey Journal of Communication, 7(2), 206-215.

Girardelli, D. (2017). Impromptu speech gamification for ESL/EFL students. Communication Teacher, 31(3), 156-161. https://doi.org/10.1080/17404622.2017.1314522

Gui, M. (2012). Exploring differences between Chinese and American EFL teachers' evaluations of speech $\begin{array}{llll}\text { performance. } \quad \text { Language Assessment } & \text { Quarterly, }\end{array}$ https://doi.org/10.1080/15434303.2011.614030

Hampton, C. (1967). Exit extemporaneous. Today's Speech, 15(2), 7-10. Cited in Rumbough, T. B. (1999). The effects of impromptu speech exercises on reducing trait and situational communication apprehension. The New Jersey Journal of Communication, 7(2), 206-215. https://doi.org/10.1080/01463376709368816

Heinz, M. (2013). Impromptu Speaking and Interpretation Studies: A Preliminary Study. Journal of International Education Research, 9(4), 387-396. https://doi.org/10.19030/jier.v9i4.8140

Hendrix, J. A. (1968). Teaching devices: A symposium. Speech Teacher, 17(4), 334-335. https://doi.org/10.1080/03634526809377704

Kapp, K. M. (2012). Games, Gamification, and the quest for learner engagement. Training \& Development, 66 (6), 64-88.

Lucas, S. E. (1998). Instructor's manual to accompany the art of public speaking (6th ed.) New York, NY: McGraw Hill.

Lucas, S. E. (2012). The Art of Public Speaking. 11th Edition. New York: McGraw-Hill.

MacIntyre, P. D., \& Renée MacDonald, J. (1998). Public speaking anxiety: Perceived competence and audience congeniality. Communication Education, 47(4), 359-365. https://doi.org/10.1080/03634529809379142

Metcafle, S. (2010). Building a Speech (7th edition). Wadsworth, Cengage learning.

Morreale, S. P., \& Pearson, J. C. (2008). Why communication education is important: The centrality of the discipline in the 21stcCentury. Communication Education, 57(2), 224-240. https://doi.org/10.1080/03634520701861713

Morreale, S., Hackman, M. \& Neer, R. (1998). Predictors of self-perceptions of behavioral competence, self-esteem, and willingness to communicate: A study assessing impact in a basic interpersonal course. Basic Communication Course Annual, 10, 7-26. 
Morreale, S., Hackman, M., \& Neer, R. (1995). Predictors of behavioral competence and self-esteem: A study assessing impact in a basic public speaking course. Basic Communication Course Annual, 7, 125-141.

Paul, A. K. (1965). An old idea made new-speakeasy. Central States Speech Journal, 16(2), 126-128. https://doi.org/10.1080/10510976509362782

Peterson, S. A. (2007). Towards Curtailing Speaker Anxiety Via Impromptu and Oral Interpretation. Communication and Theater Association of Minnesota Journal, 34, 113-118.

Puigcerver, A., Martinez-Selva, J. M., Garcia-Sanchez, F. A., \& Gomez-Amor, J. (1989). Individual differences in psychophysiological and subjective correlates of speech anxiety. Journal of Psychophysiology, 3(1), 75-81.

Reynolds, C. L., \& Fay, M. (1987). Competitive impromptu speaking. The National forensic Journal, V, 81-94. Cited in Rumbough, T. B. (1999). The effects of impromptu speech exercises on reducing trait and situational communication apprehension. The New Jersey Journal of Communication, 7(2), 206-215.

Rumbough, T. B. (1999). The effects of impromptu speech exercises on reducing trait and situational communication apprehension. The New Jersey Journal of Communication, 7(2), 206-215. https://doi.org/10.1080/15456879909367368

Schreiber, M. Lisa, Paul, Gregory, D. and Shibley, Lisa, R. (2012). The Development and Test of the Public Speaking Competence Rubric. Communication Education, 36(3), 205-233. https://doi.org/10.1080/03634523.2012.670709

Sellnow, T. L. (1989). "Proving it" in impromptu speaking. The Forensic of Pi Kappa Delta, 75(1), 7-13. Cited in Rumbough, T. B. (1999). The effects of impromptu speech exercises on reducing trait and situational communication apprehension. The New Jersey Journal of Communication, 7(2), 206-215.

Sidelinger, R. J., Myers, S. A., \& McMullen, A. L. (2011). Students' communication predispositions: An examination of classroom connectedness in public speaking courses. Basic Communication Course Annual, 23(1), 13.

Verderber, F. R., Sellnow, D., \& Verderber, K. (2012). The Challenge of Effective Speaking. 15th edition. Boston: Wadsworth, Cengage learning.

Walser, F. E. (1959). Some call it guts. Today's Speech, 7(3), 19-29 cited in Rumbough, T. B. (1999). The effects of impromptu speech exercises on reducing trait and situational communication apprehension. The New Jersey Journal of Communication, 7(2), 206-215. https://doi.org/10.1080/01463375909389519

Weaver, R. R., \& Qi, J. (2005). Classroom organization and participation: College students' perceptions. The Journal of Higher Education, 76(5), 570-601. https://doi.org/10.1353/jhe.2005.0038

Yu-Chih, S. (2008). The Toastmasters approach: An innovative way to teach public speaking to EFL learners in Taiwan. RELC Journal, 39(1), 113-130. https://doi.org/10.1177/0033688208091143 


\section{Appendix}

Public Speaking Competence Rubric

\begin{tabular}{|c|c|c|c|c|c|}
\hline \multirow{3}{*}{$\begin{array}{l}\text { Performance } \\
\text { standard } \\
\text { The student ... }\end{array}$} & \multicolumn{5}{|c|}{ Assessment Criteria } \\
\hline & Advanced & Proficient & Basic & Minimal & Deficient \\
\hline & 4 & 3 & 2 & 1 & 0 \\
\hline $\begin{array}{l}\text { 1. Selects a topic } \\
\text { appropriate to } \\
\text { the audience and } \\
\text { occasion }\end{array}$ & $\begin{array}{l}\text { Topic engages audience; } \\
\text { topic is worthwhile, } \\
\text { timely, and presents new } \\
\text { information to the } \\
\text { audience }\end{array}$ & $\begin{array}{l}\text { Topic is appropriate to } \\
\text { the audience and } \\
\text { situation and provides } \\
\text { some useful information } \\
\text { to the audience }\end{array}$ & $\begin{array}{l}\text { Topic is untimely or lacks } \\
\text { originality; provides } \\
\text { scant new information to } \\
\text { audience }\end{array}$ & $\begin{array}{l}\text { Topic is too trivial, too } \\
\text { complex, or } \\
\text { inappropriate for } \\
\text { audience; topic not } \\
\text { suitable for the situation }\end{array}$ & $\begin{array}{l}\text { A single topic cannot be } \\
\text { deduced }\end{array}$ \\
\hline $\begin{array}{l}\text { 2. Formulates an } \\
\text { introduction that } \\
\text { orients audience } \\
\text { to topic and } \\
\text { speaker }\end{array}$ & $\begin{array}{l}\text { Excellent attention } \\
\text { getter; firmly establishes } \\
\text { credibility; sound } \\
\text { orientation to topic; } \\
\text { clear thesis; preview of } \\
\text { main points cogent and } \\
\text { memorable }\end{array}$ & $\begin{array}{l}\text { Good attention getter; } \\
\text { generally establishes } \\
\text { credibility; provides some } \\
\text { orientation to topic; } \\
\text { discernible thesis; } \\
\text { previews main points }\end{array}$ & $\begin{array}{l}\text { Attention getter is } \\
\text { mundane; somewhat } \\
\text { develops credibility; } \\
\text { awkwardly composed } \\
\text { thesis; provides little } \\
\text { direction for audience }\end{array}$ & $\begin{array}{l}\text { Irrelevant opening; little } \\
\text { attempt to build } \\
\text { credibility; abrupt jump } \\
\text { into body of speech; } \\
\text { thesis and main points } \\
\text { can be deduced but are } \\
\text { not explicitly stated }\end{array}$ & $\begin{array}{l}\text { No opening technique; no } \\
\text { credibility statement; no } \\
\text { background on topic; no } \\
\text { thesis; no preview of points }\end{array}$ \\
\hline $\begin{array}{l}\text { 3. Uses an effective } \\
\text { organizational } \\
\text { pattern }\end{array}$ & $\begin{array}{l}\text { Very well organized; } \\
\text { main points clear, } \\
\text { mutually exclusive and } \\
\text { directly related to thesis; } \\
\text { effective transitions and } \\
\text { signposts }\end{array}$ & $\begin{array}{l}\text { Organizational pattern is } \\
\text { evident, main points are } \\
\text { apparent; transitions } \\
\text { present between main } \\
\text { points; some use of } \\
\text { signposts }\end{array}$ & $\begin{array}{l}\text { Organizational pattern } \\
\text { somewhat evident; main } \\
\text { points are present but } \\
\text { not mutually exclusive; } \\
\text { transitions are present } \\
\text { but are minimally } \\
\text { effective }\end{array}$ & $\begin{array}{l}\text { Speech did not flow well; } \\
\text { speech was not logically } \\
\text { organized; transitions } \\
\text { present but not well } \\
\text { formed }\end{array}$ & $\begin{array}{l}\text { No organizational pattern; } \\
\text { no transitions; sounded as if } \\
\text { information was randomly } \\
\text { presented }\end{array}$ \\
\hline
\end{tabular}

\begin{tabular}{|c|c|c|c|c|c|}
\hline \multirow{2}{*}{$\begin{array}{l}\text { Performance } \\
\text { standard } \\
\text { The student ... }\end{array}$} & \multicolumn{5}{|c|}{ Assessment Criteria } \\
\hline & $\begin{array}{c}\text { Advanced } \\
4\end{array}$ & $\begin{array}{l}\text { Proficient } \\
3\end{array}$ & $\begin{array}{c}\text { Basic } \\
2\end{array}$ & $\underset{1}{\text { Minimal }}$ & $\begin{array}{l}\text { Deficient } \\
0\end{array}$ \\
\hline $\begin{array}{l}\text { 4. Locates, } \\
\text { synthesizes and } \\
\text { employs } \\
\text { compelling } \\
\text { supporting } \\
\text { materials }\end{array}$ & $\begin{array}{l}\text { All key points are well } \\
\text { supported with a variety } \\
\text { of credible materials } \\
\text { (e.g., facts, stats, quotes, } \\
\text { etc.); sources provide } \\
\text { excellent support for } \\
\text { thesis; all sources clearly } \\
\text { cited }\end{array}$ & $\begin{array}{l}\text { Main points were } \\
\text { supported with } \\
\text { appropriate material; } \\
\text { sources correspond } \\
\text { suitably to thesis; nearly } \\
\text { all sources cited }\end{array}$ & $\begin{array}{l}\text { Points were generally } \\
\text { supported using an } \\
\text { adequate mix of } \\
\text { materials; some evidence } \\
\text { supports thesis; source } \\
\text { citations need to be } \\
\text { clarified }\end{array}$ & $\begin{array}{l}\text { Some points were not } \\
\text { supported; a greater } \\
\text { quantity/quality of } \\
\text { material needed; some } \\
\text { sources of very poor } \\
\text { quality }\end{array}$ & $\begin{array}{l}\text { Supporting materials are } \\
\text { nonexistent or are not cited }\end{array}$ \\
\hline $\begin{array}{l}\text { 5. Develops a } \\
\text { conclusion that } \\
\text { reinforces the } \\
\text { thesis and } \\
\text { provides } \\
\text { psychological } \\
\text { closure }\end{array}$ & $\begin{array}{l}\text { Provides a clear and } \\
\text { memorable summary of } \\
\text { points; refers back to } \\
\text { thesis/big picture; ends } \\
\text { with strong clincher or } \\
\text { call to action }\end{array}$ & $\begin{array}{l}\text { Appropriate summary of } \\
\text { points; some reference } \\
\text { back to thesis; clear } \\
\text { clincher or call to action }\end{array}$ & $\begin{array}{l}\text { Provides some summary } \\
\text { of points; no clear } \\
\text { reference back to thesis; } \\
\text { closing technique can be } \\
\text { strengthened }\end{array}$ & $\begin{array}{l}\text { Conclusion lacks clarity; } \\
\text { trails off; ends in a tone } \\
\text { at odds with the rest of } \\
\text { the speech }\end{array}$ & $\begin{array}{l}\text { No conclusion; speech ends } \\
\text { abruptly and without } \\
\text { closure }\end{array}$ \\
\hline $\begin{array}{l}\text { 6. Demonstrates a } \\
\text { careful choice of } \\
\text { words }\end{array}$ & $\begin{array}{l}\text { Language is } \\
\text { exceptionally clear, } \\
\text { imaginative and vivid; } \\
\text { completely free from } \\
\text { bias, grammar errors } \\
\text { and inappropriate usage }\end{array}$ & $\begin{array}{l}\text { Language appropriate to } \\
\text { the goals of the } \\
\text { presentation; no } \\
\text { conspicuous errors in } \\
\text { grammar; no evidence of } \\
\text { bias }\end{array}$ & $\begin{array}{l}\text { Language selection } \\
\text { adequate; some errors in } \\
\text { grammar; language at } \\
\text { times misused (e.g., } \\
\text { jargon, slang, awkward } \\
\text { structure) }\end{array}$ & $\begin{array}{l}\text { Grammar and syntax } \\
\text { need to be improved as } \\
\text { can level of language } \\
\text { sophistication; } \\
\text { occasionally biased }\end{array}$ & $\begin{array}{l}\text { Many errors in grammar } \\
\text { and syntax; extensive use of } \\
\text { jargon, slang, sexist/racist } \\
\text { terms or mispronunciations }\end{array}$ \\
\hline $\begin{array}{l}\text { 7. Effectively uses } \\
\text { vocal expression } \\
\text { and paralanguage } \\
\text { to engage the } \\
\text { audience }\end{array}$ & $\begin{array}{l}\text { Excellent use of vocal } \\
\text { variation, intensity and } \\
\text { pacing; vocal expression } \\
\text { natural and } \\
\text { enthusiastic; avoids } \\
\text { fillers }\end{array}$ & $\begin{array}{l}\text { Good vocal variation and } \\
\text { pace; vocal expression } \\
\text { suited to assignment; few } \\
\text { if any fillers }\end{array}$ & $\begin{array}{l}\text { Demonstrates some vocal } \\
\text { variation; enunciates } \\
\text { clearly and speaks } \\
\text { audibly; generally avoids } \\
\text { fillers (e.g., um, uh, like) }\end{array}$ & $\begin{array}{l}\text { Sometimes uses a voice } \\
\text { too soft or articulation } \\
\text { too indistinct for } \\
\text { listeners to comfortably } \\
\text { hear; often uses fillers }\end{array}$ & $\begin{array}{l}\text { Speaks inaudibly; } \\
\text { enunciates poorly; speaks in } \\
\text { monotone; poor pacing; } \\
\text { distracts listeners with fillers }\end{array}$ \\
\hline
\end{tabular}




\begin{tabular}{|c|c|c|c|c|c|}
\hline \multirow{2}{*}{$\begin{array}{l}\text { Performance } \\
\text { standard } \\
\text { The student ... }\end{array}$} & \multicolumn{5}{|c|}{ Assessment Criteria } \\
\hline & $\begin{array}{c}\text { Advanced } \\
4\end{array}$ & $\begin{array}{c}\text { Proficient } \\
3\end{array}$ & $\begin{array}{c}\text { Basic } \\
2\end{array}$ & $\begin{array}{c}\text { Minimal } \\
1\end{array}$ & $\begin{array}{c}\text { Deficient } \\
0\end{array}$ \\
\hline $\begin{array}{l}\text { 8. Demonstrates } \\
\text { nonverbal } \\
\text { behavior that } \\
\text { supports the } \\
\text { verbal message }\end{array}$ & $\begin{array}{l}\text { Posture, gestures, facial } \\
\text { expression and eye } \\
\text { contact well developed, } \\
\text { natural, and display } \\
\text { high levels of poise and } \\
\text { confidence }\end{array}$ & $\begin{array}{l}\text { Postures, gestures and } \\
\text { facial expressions are } \\
\text { suitable for speech, } \\
\text { speaker appears confident }\end{array}$ & $\begin{array}{l}\text { Some reliance on notes, } \\
\text { but has adequate eye } \\
\text { contact, generally avoids } \\
\text { distracting mannerisms }\end{array}$ & $\begin{array}{l}\text { Speaker relies heavily on } \\
\text { notes; nonverbal } \\
\text { expression stiff and } \\
\text { unnatural }\end{array}$ & $\begin{array}{l}\text { Usually looks down and } \\
\text { avoids eye con-tact; nervous } \\
\text { gestures and nonverbal } \\
\text { behaviors distract from or } \\
\text { contradict the message }\end{array}$ \\
\hline $\begin{array}{l}\text { 9. Successfully } \\
\text { adapts the } \\
\text { presentation to } \\
\text { the audience }\end{array}$ & $\begin{array}{l}\text { Speaker shows how } \\
\text { information is } \\
\text { personally important to } \\
\text { audience; speech is } \\
\text { skillfully tailored to } \\
\text { audience beliefs, values, } \\
\text { and attitudes; speaker } \\
\text { makes allusions to } \\
\text { culturally shared } \\
\text { experiences } \\
\text { nce Standards (To be added }\end{array}$ & $\begin{array}{l}\text { Speaker implies the } \\
\text { importance of the topic } \\
\text { to the audience; } \\
\text { presentation is adapted to } \\
\text { audience beliefs, attitudes } \\
\text { and values; an attempt is } \\
\text { made to establish } \\
\text { common ground } \\
\text { to grading rubric as needer }\end{array}$ & $\begin{array}{l}\text { Speaker assumes but does } \\
\text { not articulate the } \\
\text { importance of topic; } \\
\text { presentation was } \\
\text { minimally adapted to } \\
\text { audience beliefs, } \\
\text { attitudes, and values; } \\
\text { some ideas in speech are } \\
\text { removed from audience's } \\
\text { frame of reference or } \\
\text { experiences } \\
\text { d) }\end{array}$ & $\begin{array}{l}\text { The importance of topic } \\
\text { is not established; very } \\
\text { little evidence of } \\
\text { audience adaptation; } \\
\text { speaker needs to more } \\
\text { clearly establish a } \\
\text { connection with the } \\
\text { audience }\end{array}$ & $\begin{array}{l}\text { Speech is contrary to } \\
\text { audience beliefs, values, and } \\
\text { attitudes; message is generic } \\
\text { or canned; no attempt is } \\
\text { made to establish common } \\
\text { ground }\end{array}$ \\
\hline $\begin{array}{l}\text { 10. Skillfully makes } \\
\text { use of visual aids }\end{array}$ & $\begin{array}{l}\text { Exceptional explanation } \\
\text { and presentation of } \\
\text { visual aids; visuals } \\
\text { provide powerful } \\
\text { insight into speech } \\
\text { topic; visual aids of high } \\
\text { professional quality }\end{array}$ & $\begin{array}{l}\text { Visual aids well } \\
\text { presented; use of visual } \\
\text { aids enhances } \\
\text { understanding; visual } \\
\text { aids good quality }\end{array}$ & $\begin{array}{l}\text { Visual aids were generally } \\
\text { well displayed and } \\
\text { explained; minor errors } \\
\text { present in visuals }\end{array}$ & $\begin{array}{l}\text { Speaker did not seem } \\
\text { well practiced with } \\
\text { visuals; visuals not fully } \\
\text { explained; quality of } \\
\text { visuals needs } \\
\text { improvement }\end{array}$ & $\begin{array}{l}\text { Use of the visual aids } \\
\text { distracted from the speech; } \\
\text { visual aids not relevant; } \\
\text { visual aids poor } \\
\text { professional quality }\end{array}$ \\
\hline \multirow{2}{*}{$\begin{array}{l}\text { Performance } \\
\text { standard } \\
\text { The student ... }\end{array}$} & \multicolumn{5}{|c|}{ Assessment Criteria } \\
\hline & $\begin{array}{c}\text { Advanced } \\
4\end{array}$ & $\begin{array}{c}\text { Proficient } \\
3\end{array}$ & $\begin{array}{c}\text { Basic } \\
2\end{array}$ & $\underset{1}{\text { Minimal }}$ & $\begin{array}{c}\text { Deficient } \\
0\end{array}$ \\
\hline $\begin{array}{l}\text { 11. Constructs an } \\
\text { effectual } \\
\text { persuasive } \\
\text { message with } \\
\text { credible evidence } \\
\text { and sound } \\
\text { reasoning }\end{array}$ & $\begin{array}{l}\text { Articulates problem and } \\
\text { solution in a clear, } \\
\text { compelling manner; } \\
\text { supports claims with } \\
\text { powerful/credible } \\
\text { evidence; completely } \\
\text { avoids reasoning } \\
\text { fallacies; memorable call } \\
\text { to action }\end{array}$ & $\begin{array}{l}\text { Problem and solution are } \\
\text { clearly presented; claims } \\
\text { supported with evidence } \\
\text { and examples; sound } \\
\text { reasoning evident; clear } \\
\text { call to action }\end{array}$ & $\begin{array}{l}\text { Problem and solution are } \\
\text { evident; most claims are } \\
\text { supported with evidence; } \\
\text { generally sound } \\
\text { reasoning; recognizable } \\
\text { call to action }\end{array}$ & $\begin{array}{l}\text { Problem and/or solution } \\
\text { are somewhat unclear; } \\
\text { claims not fully } \\
\text { supported with evidence; } \\
\text { some reasoning fallacies } \\
\text { present; call to action } \\
\text { vague }\end{array}$ & $\begin{array}{l}\text { Problem and/or solution } \\
\text { are not defined; claims not } \\
\text { supported with evidence; } \\
\text { poor reasoning; no call to } \\
\text { action }\end{array}$ \\
\hline
\end{tabular}

Lisa Schreiber 2010 Reprinted with permission.

\section{Copyrights}

Copyright for this article is retained by the author(s), with first publication rights granted to the journal.

This is an open-access article distributed under the terms and conditions of the Creative Commons Attribution license (http://creativecommons.org/licenses/by/4.0/). 